\title{
Powództwo przeciw dyskryminacji w Ustawie z dnia 3 grudnia 2010 r. o wdrożeniu niektórych przepisów Unii Europejskiej w zakresie równego traktowania
}

\section{Wprowadzenie}

Dyskryminacja jest zjawiskiem towarzyszącym społeczeństwu od wielu lat ${ }^{1}$. Początkowo głównym przedmiotem regulacji była dyskryminacja w obrębie prawa pracy i w relacji pracodawca-pracownik. Inicjatywa organów Unii Europejskiej spowodowała jednak konieczność implementacji dalej idących regulacji prawnych dotyczących zjawiska dyskryminacji. Termin "dyskryminacja” pochodzi od łacińskiego słowa discriminatio i oznacza "oddzielenie” lub „rozdzielenie” ${ }^{2}$. W naukach społecznych przez dyskryminację rozumie się niesprawiedliwe, wybiórcze, krzywdzące, niewłaściwe traktowanie osób w związku z ich przynależnością do pewnej społecznie rozpoznawalnej grupy, wyodrębnionej na podstawie jednej lub większej liczby cech-tożsamości, np. kobiet (płeć), osób starszych (wiek) czy też muzułmanów (wyznanie) $)^{3}$. Jest ona zaprzeczeniem

${ }^{1}$ G.C. Pierson, S.R. Fulkerson, M.F. Lauerdale, Age Discrimination in the Workplace: A Primer for Human Resource Professionals, Society for Human Resource Management 1999; J.F. Healey, Diversity and Society: Race, Ethnicity, and Gender, Los Angeles-London-New Delhi-Singapore-Washington 2010; I. Solanke, Discrimination as Stigma: A Theory of Anti-discrimination Law, London 2016; P.T. Jaeger, C.A. Bowman, Understanding Disability: Inclusion, Access, Diversity, and Civil Rights, Westport, CT-London 2005; Racism and Equal Opportunity Policies in the 1980s, ed. by R. Jenkins, J. Solomos, Cambridge 1989.

2 Stownikjęzyka polskiego, https://sjp.pl/dyskryminacja (dostęp: 15 VIII 2017).

${ }^{3}$ Z. Jabłońska, Dyskryminacja - wprowadzenie do pojęcia, w: Ustawa o wdrożeniu niektórych przepisów Unii Europejskiej w zakresie równego traktowania. Komentarz, pod red. K. Kędziory i in., Warszawa 2017, s. 17. 
zasady równości i stanowi afront dla godności ludzkiej. Trybunał Konstytucyjny w swoim orzecznictwie podkreśla, że "dyskryminacja” to „nienadające się do zaakceptowania tworzenie różnych norm prawnych dla podmiotów prawa, które powinny być zaliczone do tej samej klasy (kategorii), albo nierówne traktowanie podobnych podmiotów prawa w indywidualnych przypadkach, gdy zróżnicowanie nie znajduje podstaw w normach prawnych" ${ }^{4}$. Pogłębia ona status quo w społeczeństwie, zmierzając do utrzymania uprzywilejowanej pozycji grupy dominującej, przy jednoczesnej marginalizacji grup mniejszościowych ${ }^{5}$.

U podstaw dyskryminacji leżą cechy osobowościowe człowieka. W doktrynie podkreśla się, że cechy osobowościowe określają, kim jest jednostka w sensie społecznym. Wyróżnia się podział cech osobowościowych człowieka na tożsamości społeczne - pierwotne oraz wtórne. Do tożsamości pierwotnych zalicza się cechy wrodzone, a więc co do zasady niezależne od woli jednostki (wiek, płeć, orientację psychoseksualną czy pochodzenie etniczne i narodowe). Natomiast tożsamości wtórne to takie, na których zmianę mają wpływ działania jednostki, jak chociażby status jej rodziny lub też status ekonomiczny samej jednostki ${ }^{6}$.

Głównym celem opracowania jest zarysowanie instytucji powództwa przeciw dyskryminacji na tle przepisów Ustawy z dnia 3 grudnia $2010 \mathrm{r}$. o wdrożeniu niektórych przepisów Unii Europejskiej w zakresie równego traktowania ${ }^{7}$. W tym celu analizie poddano: podstawy normatywne badanej instytucji powództwa, prawo do odszkodowania, przesłanki materialno-prawne powództwa, zasady i tryb dochodzenia odszkodowania.

\section{Geneza uchwalenia ustawy równościowej}

Uchwalenie przez polskiego ustawodawcę ustawy równościowej jest konsekwencją zobowiązań Rzeczypospolitej Polskiej wynikających z obecności w Unii Europejskiej, która w sposób jednoznaczny, zarówno w prawie traktatowym, jak i wtórnym, zakazuje dyskryminacji z takich względów, jak płeć, rasa, niepełnosprawność, pochodzenie etniczne,

${ }^{4}$ Wyrok Trybunału Konstytucyjnego (TK) z 15 VII 2007 r., sygn. K 63/07, OTK-A 2010, nr 6, poz. 60 .

${ }^{5}$ A. Winiarska, W. Klaus, Dyskryminacja i nierówne traktowanie jako zjawisko społeczno-kulturowe, „Studia BAS” 2011, nr 2(26), s. 9-40.

${ }^{6}$ Ibidem, s. 17-18.

${ }^{7}$ Ustawa z dnia 3 XII 2010 r. o wdrożeniu niektórych przepisów Unii Europejskiej w zakresie równego traktowania (tekst jedn. Dz.U. 2016, poz. 1219), dalej „ustawa równościowa” lub „u.o.r.". 
orientacja seksualna, religia czy wyznanie. Polska była zobowiązana do implementacji wielu dyrektyw traktujących o przedmiotowej materii ${ }^{8}$. Ustawa ta wprowadziła do polskiego systemu prawnego przepisy, których głównym celem jest ustanowienie gwarancji materialnoprawnych, procesowych oraz instytucjonalnych - $w$ takich dziedzinach, jak swobodny przepływ usług, osób czy kapitału. Oczywiście, z pola widzenia nie należy tracić faktu, że już w 2004 r. w Kodeksie pracy ${ }^{9}$ wprowadzono regulacje zabraniające dyskryminacji ${ }^{10}$, jednakże ustawa wdrażająca przepisy unijne traktuje o zjawisku dyskryminacji bardziej kompleksowo, nie ograniczając zakresu zastosowania wyłącznie do materii związanej z relacją pracodawca-pracownik ${ }^{11}$.

\section{Cechy objęte ochroną prawną w ustawie równościowej}

Prawodawca już w art. 1 ustawy równościowej określa główny cel tego aktu. Jest nim zapobieganie naruszeniom zasady równego traktowania we wskazanych obszarach i określonymi sposobami. Ustala katalog cech uznanych za prawnie chronione, a także odnosi się do kwestii

${ }^{8}$ Dyrektywa Rady 2004/113/WE z dnia 13 XII 2004 r. wprowadzająca w życie zasadę równego traktowania mężczyzn i kobiet w zakresie dostępu do towarów i usług oraz dostarczania towarów i usług (Dz.Urz. UE L 373 z 21 XII 2004 r. ze zm., s. 37); Dyrektywa 2006/54/WE Parlamentu Europejskiego i Rady z dnia 5 VII 2006 r. w sprawie wprowadzenia $\mathrm{w}$ życie zasady równości szans oraz równego traktowania kobiet i mężczyzn w dziedzinie zatrudnienia i pracy (Dz.Urz. UE L 204 z 26 VII 2006 r., s. 23) - podsumowująca przepisy wydawanych od lat siedemdziesiątych XX w. dyrektyw mających na celu zagwarantowanie przestrzegania zasady równości kobiet i mężczyzn; Dyrektywa 2000/78/WE odnosząca się do zakazu dyskryminacji ze względu na religię, przekonania, wiek, niepełnosprawność oraz orientację seksualną (Dz.Urz. UE L 303 z 2 XIII 2000 r., s. 16-22); Dyrektywa Rady 2000/43/WE z dnia 29 VI 2000 r. wprowadzająca w życie zasadę równego traktowania bez względu na pochodzenie rasowe lub etniczne (Dz.Urz. UE L 180 z 19 VII 2000 r., s. 22); Dyrektywa Parlamentu Europejskiego i Rady z dnia 16 IV 2014 r. w sprawie środków ułatwiających korzystanie z praw przyznanych pracownikom w kontekście swobodnego przepływu pracowników (Dz.Urz. UE L 128 z 30 IV 2014 r., s. 8).

${ }^{9}$ Ustawa z dnia 26 VI 1974 r. Kodeks pracy (tekst jedn. Dz.U. 2016, poz. 1666), dalej "Kodeks pracy" lub „k.p.”.

${ }^{10} \mathrm{~W}$ szczególności przepis art. $18^{3 a}$, który stanowi, że "Jakakolwiek dyskryminacja w zatrudnieniu, bezpośrednia lub pośrednia, w szczególności ze względu na płeć, wiek, niepełnosprawność, rasę, religię, narodowość, przekonania polityczne, przynależność związkowa, pochodzenie etniczne, wyznanie, orientację seksualną, a także ze względu na zatrudnienie na czas określony lub nieokreślony albo w pełnym lub $\mathrm{w}$ niepełnym wymiarze czasu pracy - jest niedopuszczalna".

${ }^{11}$ Zob. M. Kuba, Zakaz dyskryminacji w zatrudnieniu pracowniczym, Warszawa 2017; J. Marciniak, Mobbing, dyskryminacja, molestowanie. Przeciwdziałanie w praktyce, Warszawa 2014. 
instytucjonalnej ochrony przed nierównym traktowaniem. W tym przepisie precyzyjnie wskazano kryteria podlegające ochronie. Ustawodawca zaliczył do nich: płeć, rasę, pochodzenie etniczne, narodowość, religię, wyznanie, światopogląd, niepełnosprawność, wiek oraz orientację seksualną. Cechy te nie mogą zostać uznane za relewantne, a więc za obiektywizujące czynniki dyferencjacji traktowania podmiotu objętego ochroną ${ }^{12}$. Jest to katalog zamknięty, co różni przedmiotową ustawę od przejawów dyskryminacji wskazanych w Kodeksie pracy, w którym ustawodawca pozostawił katalog otwarty, wskazując jedynie przykładowe rodzaje cech dyskryminacyjnych. Wyżej przedstawiona lista jest co do zasady tożsama z cechami, na które wskazują dyrektywy unijne. Polski ustawodawca zdecydował się na poszerzenie przedmiotowego katalogu o cechę narodowości. Negatywnie należy jednak ocenić brak zdefiniowania przez ustawodawcę samego pojęcia "narodowości". Konieczne jest zatem odwołanie do innych źródeł. Według K. Śmiszka "za nieobiektywną przesłankę dyferencjacji należy uznać osoby cechujące się nie tylko przynależnością do mniejszości narodowej objętej ochroną przez ustawę o mniejszościach narodowych i etnicznych oraz o języku regionalnym ${ }^{13}$, lecz także takie osoby, które z uwagi na swoją narodowość mogą być narażone na dyskryminacyjne traktowanie ${ }^{\prime \prime 14}$. Ustawodawca nie zdecydował się jednak na otwarcie lub rozszerzenie katalogu, tym samym postępując wbrew tendencji mającej obecnie miejsce w innych państwach unijnych, gdzie rozszerzany jest katalog cech dyskryminacyjnych chronionych przez prawo ${ }^{15}$. Zabieg ten należy ocenić negatywnie. Wprowadzenie katalogu otwartego umożliwiłoby sądom rozszerzenie zakresu zastosowania ustawy równościowej w przypadkach tego wymagających. Obecne rozwiązanie $\mathrm{w}$ przyszłości może prowadzić do ograniczenia ochrony niektórych podmiotów, dyskryminowanych ze względu na inne cechy. Nie oznacza to, że zostały one pozbawione prawnych instrumentów, mają wszak do dyspozycji środki procesowe przyznane w Kodeksie cywilnym ${ }^{16}$, które ukierunkowane są na ochronę dóbr osobistych.

${ }^{12}$ K. Śmiszek, Uwagi do art. 1, w: Ustawa o wdrożeniu niektórych przepisów Unii Europejskiej..., s. 69-71.

${ }^{13}$ Ustawa z dnia 6 I 2005 r. o mniejszościach narodowych i etnicznych oraz o języku regionalnym (tekst jedn. Dz.U. 2017, poz. 823).

${ }^{14}$ K. Śmiszek, Uwagi do art. 1, op. cit., s. 71.

${ }^{15}$ R. Grzeszczak, Opinia prawna dla Polskiego Towarzystwa Prawa Antydyskryminacyjnego, http://ptpa.org.pl/site/assets/files/1138/grzeszczak_opinia_prawna_dla_ptpa_1. pdf, s. 7 i n. (dostęp: 24 VII 2017).

${ }^{16}$ Ustawa dnia 23 IV 1964 r. Kodeks cywilny (tekst jedn. Dz.U. 2016, poz. 380), dalej „k.c.”. 
Z pola widzenia nie należy także tracić okoliczności, iż w toku prac nad przedmiotową ustawą Biuro Analiz Sejmowych oraz szereg organizacji pozarządowych podnosiło wątpliwości co do zgodności części przepisów ustawy równościowej z Konstytucją Rzeczypospolitej Polskiej ${ }^{17}$. Zwracano uwagę na zawężenie ochrony przed dyskryminacją tylko do enumeratywnie wymienionych cech (wskazanych przez ustawodawcę w art. 1, art. 3 pkt 1 i 2 ustawy równościowej), podczas gdy Konstytucja RP zakazuje dyskryminacji z jakiejkolwiek przyczyny ${ }^{18}$. Podnoszone zastrzeżenia są niewątpliwie zasadne z punktu widzenia art. 32 ust. 2 Konstytucji RP ${ }^{19}$. Trybunał Konstytucyjny (TK) w swoim orzecznictwie podkreśla, że istnienie w art. 32 ust. 2 Konstytucji RP zakazu dyskryminacji jest konsekwencją zasady równości („kwalifikowaną postacią zasady równości z art. 32 ust. 1 Konstytucji" ${ }^{20}$. Wyraża on uniwersalny charakter zasady równości, nakazując jej przestrzeganie we wszystkich sferach życia - zarówno w życiu politycznym, społecznym, jak i gospodarczym oraz określa granice dopuszczalnych różnicowań podmiotów prawa ${ }^{21}$. Zakaz wprowadzania zróżnicowań o nieuzasadnionym (arbitralnym) charakterze obejmuje zarówno zakaz wprowadzania unormowań pogarszających sytuację określonej grupy podmiotów (dyskryminacja sensu stricto), jak i unormowań polepszających sytuację określonej grupy podmiotów (uprzywilejowanie) kosztem innych grup ${ }^{22}$. Wyklucza różnicowanie sytuacji prawnej adresatów norm wyłącznie ze względu na ich cechy indywidualne (osobowe) ${ }^{23}$. Ponadto należy zauważyć, że wymienionych sfer, w których art. 32 ust. 2 Konstytucji RP zakazuje dyskryminacji, nie należy traktować jako enumeratywnych ${ }^{24}$.

${ }^{17}$ Konstytucja Rzeczypospolitej Polskiej z dnia 2 IV 1997 r. (Dz.U. Nr 78, poz. 483 ze zm.), dalej „Konstytucja RP”.

${ }^{18}$ Zob. stanowisko Koalicji na Rzecz Równych Szans z dnia 19 VI 2010 r., https:// interwencjaprawna.pl/docs/19_06_2010_stanowisko_koalicji.pdf (dostęp: 24 VII 2017); Opinia prawna BAS z dnia 18 X 2010 r., http:// orka.sejm.gov.pl/rexdomk6.nsf/ Opdodr?OpenPage\&nr=3386 (dostęp: 24 VII 2017).

${ }^{19}$ Zgodnie z art. 32 ust. 1 i 2 Konstytucji RP „Wszyscy są wobec prawa równi. Wszyscy mają prawo do równego traktowania przez władze publiczne. [...] Nikt nie może być dyskryminowany w życiu politycznym, społecznym lub gospodarczym z jakiejkolwiek przyczyny".

${ }^{20}$ Wyrok TK z 15 VII 2007 r., sygn. K 63/07, OTK-A 2010, nr 6, poz. 60.

${ }^{21}$ Wyrok TK z 24 X 2001 r., sygn. SK 22/01, OTK 2001, nr 7, poz. 216.

${ }^{22}$ Orzeczenie TK z 9 III 1988 r., sygn. U 7/87, OTK 1988, nr 1, poz. 1.

${ }^{23}$ Wyrok TK z 5 VII 2011 r., sygn. P 14/10, OTK-A 2011, nr 6, poz. 49.

${ }^{24}$ W. Borysiak, L. Bosek, Uwagi do art. 32, w: Konstytucja RP, t. 1: Komentarze do art. 1-86, pod red. M. Safjana, L. Boska, Warszawa 2016. 
Ustrojodawca, wprowadzając zakaz dyskryminacji, nie określa cech, ze względu na które nie można dokonywać różnicowań pomiędzy podmiotami praw i wolności (tzw. cech zakazanych) ${ }^{25}$.

Z powyższego wynika, że prawodawca, powołując do życia ustawę równościowa, nie czyni zadość wymaganiom konstytucyjnym i wprowadza wąski zakres ustawowych gwarancji przestrzegania art. 32 ust. 1 Konstytucji RP. Zakres ochrony ograniczony jedynie do kilku cech prawnie chronionych stwarza wątpliwości co do zgodności przepisów ustawy ze standardami konstytucyjnymi oraz standardami prawa międzynarodowe$\mathrm{go}^{26}$. Z drugiej strony, ustawa równościowa miała na celu implementację dyrektyw UE, które określają zakres stosowania ustawy: zaliczając do niego m.in. edukację, usługi, przepływ kapitału i enumeratywnie wskazują cechy osobowościowe człowieka, na podstawie których nie wolno dyskryminować jednostki. Pomimo przedstawionych wątpliwości ustawa była dużym krokiem naprzód, pozwalającym na uzupełnienie luki w prawie.

Ochroną antydyskryminacyjną zostały objęte osoby fizyczne, osoby prawne oraz jednostki organizacyjne niebędące osobami prawnymi, którym ustawa przyznaje zdolność prawną (art. 2 u.o.r.). Fakt przyznania osobom fizycznym ochrony prawnej przed dyskryminacją nie budzi wątpliwości, jednakże stosowanie prawa antydyskryminacyjnego wobec innych podmiotów doznaje już pewnych ograniczeń, wynikających z samej ich natury. Oczywiście, osoby prawne posiadają określone dobra osobiste ${ }^{27}$, które są chronione prawnie, ale nie mają w sobie cech osobistych mogących stanowić podstawę dyskryminacji. Dlatego też należy konstatować, że ochrona prawna będzie zawsze powiązana z osobami fizycznymi tworzącymi określoną osobę prawną lub jednostkę organizacyjną ${ }^{28}$.

${ }^{25}$ Ibidem.

${ }^{26}$ Tak też Rzecznik Praw Obywatelskich (RPO) w swoim wystąpieniu z dnia $28 \mathrm{~V}$ 2012 r., www.sprawy-generalne.brpo.gov.pl/pdf/2011/10/687085/1647153.pdf (dostęp: 15 VII 2017). We wniosku Rzecznik zwróciła ponadto uwagę, że wprowadzony przez ustawodawcę katalog kryteriów objętych ochroną przed dyskryminacją potencjalnie jest niezgodny ze standardami prawa międzynarodowego, zwłaszcza z art. 14 Europejskiej Konwencji Praw Człowieka, który zakazuje dyskryminacji „wynikającej z takich powodów, jak płeć, rasa, kolor skóry, język, religia, przekonania polityczne i inne, pochodzenie narodowe lub społeczne, przynależność do mniejszości narodowej, majątek, urodzenie bądź jakichkolwiek innych przyczyn".

${ }^{27}$ Zgodnie z art. 43 k.c. przepisy o ochronie dóbr osobistych osób fizycznych stosuje się odpowiednio do osób prawnych.

${ }^{28}$ M. Kułak, Uwagi do art. 2, w: Ustawa o wdrożeniu niektórych przepisów Unii Europejskiej..., s. 79-85. 
Ustawodawca w art. 4 u.o.r. wskazuje na obszary, wobec których ma zastosowanie ustawa (jej zakres przedmiotowy) ${ }^{29}$. Zakres przedmiotowy wyznacza m.in.: edukacja, warunki podejmowania i wykonywania działalności gospodarczej lub zawodowej, uczestnictwo w związkach zawodowych, dostęp do korzystania z instrumentów rynków pracy i usług rynku pracy.

Zgodnie $\mathrm{z}$ art. 3 ustawy równościowej ustawodawca chroni podmioty dotknięte zarówno dyskryminacją bezpośrednią ${ }^{30}$, jak i jej pośrednimi przejawami ${ }^{31}$. Materia związana z kompleksowym omówieniem zjawisk dyskryminacji bezpośredniej oraz pośredniej jest zbyt szeroka, aby można było ją zawrzeć w niniejszym opracowaniu. W celu uprawdopodobnienia, że doszło do dyskryminacji, osoba dotknięta dyskryminacją powinna przeprowadzić środki dowodowe zmierzające do wykazania, że jednocześnie zaszły dwa warunki sine qua non: (1) motywem nieprzychylnego traktowania była cecha uznana przez

${ }^{29}$ Zgodnie z art. 4 u.o.r. akt ten stosuje się w zakresie: 1) podejmowania kształcenia zawodowego, w tym dokształcania, doskonalenia, przekwalifikowania zawodowego oraz praktyk zawodowych; 2) warunków podejmowania i wykonywania działalności gospodarczej lub zawodowej, w tym w szczególności w ramach stosunku pracy albo pracy na podstawie umowy cywilnoprawnej; 3) przystępowania i działania w związkach zawodowych, organizacjach pracodawców oraz samorządach zawodowych, a także korzystania z uprawnień przysługujących członkom tych organizacji; 4) dostępu i warunków korzystania $z$ : a) instrumentów rynku pracy i usług rynku pracy określonych w Ustawie z dnia 20 IV 2004 r. o promocji zatrudnienia i instytucjach rynku pracy (tekst jedn. Dz.U. 2016 r., poz. 645, 691, 868) oferowanych przez instytucje rynku pracy oraz instrumentów rynku pracy i usług rynku pracy oferowanych przez inne podmioty działające na rzecz zatrudnienia, rozwoju zasobów ludzkich i przeciwdziałania bezrobociu, b) zabezpieczenia społecznego, c) opieki zdrowotnej, d) oświaty i szkolnictwa wyższego, e) usług, w tym usług mieszkaniowych, rzeczy oraz nabywania praw i energii, jeżeli są one oferowane publicznie.

${ }^{30}$ Zgodnie z definicją legalną wskazaną w przepisie art. 3 pkt 1 przez dyskryminację bezpośrednią rozumie się sytuację, w której osoba fizyczna ze względu na płeć, rasę, pochodzenie etniczne, narodowość, religię, wyznanie, światopogląd, niepełnosprawność, wiek lub orientację seksualną jest traktowana mniej korzystnie, niż jest, była lub byłaby traktowana inna osoba w porównywalnej sytuacji.

${ }^{31}$ Zgodnie $z$ definicją legalną wskazaną w przepisie art. 3 pkt 2 rozumie się przez to sytuację, w której dla osoby fizycznej ze względu na płeć, rasę, pochodzenie etniczne, narodowość, religię, wyznanie, światopogląd, niepełnosprawność, wiek lub orientację seksualną na skutek pozornie neutralnego postanowienia, zastosowanego kryterium lub podjętego działania występują lub mogłyby wystąpić niekorzystne dysproporcje lub szczególnie niekorzystna dla niej sytuacja, chyba że postanowienie, kryterium lub działanie jest obiektywnie uzasadnione ze względu na zgodny z prawem cel, który ma być osiągnięty, a środki służące osiągnięciu tego celu są właściwe i konieczne. 
ustawodawcę za chroniona, a także (2) musi być możliwe porównanie określonego zachowania do sytuacji, w której brak określonej cechy nie spowodowałby takiego zachowania ${ }^{32}$. Oczywiście, w toku postępowania sądowego uprawdopodobnienie zaistnienia obu tych warunków mogłoby przysporzyć stronie dyskryminowanej bardzo wielu trudności dowodowych, które na etapie stosowania prawa mają kluczowe znaczenie - zwłaszcza w odniesieniu do drugiego z wymienionych warunków. Dlatego też polskie sądy, rozstrzygając zawisłe przed nimi spory, powinny odwoływać się do bogatego orzecznictwa Trybunału Sprawiedliwości, który stoi na stanowisku, że podczas ustalania dyskryminacji bezpośredniej nie jest konieczne poszukiwanie identyczności sytuacji, lecz jedynie daleko posuniętych podobieństw ${ }^{33}$. Z kolei w przypadkach dyskryminacji pośredniej należy zbadać skutki zachowań wobec osób i położenie grupy osób charakteryzujących się cechą będącą kryterium dyskryminacji ${ }^{34}$. Dyskryminacja pośrednia może zaistnieć w sytuacji, gdy podmioty będące $\mathrm{w}$ różnych sytuacjach traktuje się pozornie tak samo, lecz skutek takiego traktowania jest inny ${ }^{35}$. Dlatego też dotyczy ona zwykle dyskryminacji strukturalnej i systemowej ${ }^{36}$.

${ }^{32}$ Z. Jabłońska, Uwagi do art. 3, w: Ustawa o wdrożeniu niektórych przepisów Unii Europejskiej..., s. 86-89.

${ }^{33}$ Wyrok Trybunału Sprawiedliwości (TS) z 10 V 2011 r. w sprawie Jürgen Romerv. Frei und Hansestadt Hamburg, nr skargi C-147/08.

${ }^{34}$ Z. Jabłońska, Uwagi..., s. 94-101.

${ }^{35}$ Przykład dyskryminacji pośredniej obrazuje sprawa zawisła przed TS, numer skargi C-7/12, Nadezda Riežnice v. Zemkopības ministrija i Lauku atbalsta dienests, w której to skarżąca przebywała na kilkuletnim urlopie rodzicielskim. W 2009 r. pracodawca zdecydował się na likwidację jednego ze stanowisk pracy. W celu ustalenia, kogo dotyczyć będzie likwidacja stanowiska, pracodawca zdecydował się na przeprowadzenie konkursu, w którym pracownicy zostali poddani indywidualnej ocenie. Ustalono identyczne kryteria oraz jednolitą skalę ocen. Jednakże wobec pracownicy przebywającej na urlopie wprowadzono kryterium oceny pracy na podstawie wyników ostatniej oceny rocznej sprzed odejścia na urlop. Ponadto wszyscy pracownicy poddani ocenie mieli obowiązek osobistego stawiennictwa. W związku z różnicami w kryteriach oceniania i niemożnością osobistego stawiennictwa pracownica uzyskała najgorszy wynik i została zwolniona z pracy. W uzasadnieniu do wyroku z dnia 20 VI 2013 r. TS podkreślił, że "Ocena przeprowadzona przez pracodawcę powinna była się opierać na kryteriach ściśle identycznych zarówno wobec pracowników w danym momencie czynnych zawodowo, jak i tych, którzy w danym momencie nie są czynni zawodowo ze względu chociażby na urlop rodzicielski. Ponadto zastosowanie przedmiotowych kryteriów nie może wymagać osobistej obecności pracowników, gdyż pracownik przebywający na urlopie rodzicielskim nie może spełnić takiego warunku".

${ }^{36}$ Z. Jabłońska, Ustawa..., s. 96. 


\section{Powództwo przeciw dyskryminacji}

Ustawa równościowa przyznaje każdemu, wobec kogo zasada równego traktowania została naruszona, prawo do odszkodowania (art. 13 ust. 1 u.o.r.). Z kolei art. 14 u.o.r. przewiduje, że "[k]to zarzuca naruszenie zasady równego traktowania, uprawdopodobnia fakt jej naruszenia" (ust. 2) $\mathrm{i}$ "[w] przypadku uprawdopodobnienia naruszenia zasady równego traktowania ten, któremu zarzucono naruszenie tej zasady, jest obowiązany wykazać, że nie dopuścił się jej naruszenia" (ust. 3). Przepisy te są źródłem normatywnym tytułowego powództwa przeciw dyskryminacji.

W sprawach o naruszenie zasady równego traktowania stosuje się odpowiednio przepisy Ustawy z dnia 17 listopada 1964 r. - Kodeks postępowania cywilnego ${ }^{37}$. Jednakże $\mathrm{w}$ związku z treścią przepisów ust. 2 i 3 art. 14 u.o.r. należy wskazać, że ograniczone zostaje stosowanie art. 232 zd. 1 k.p.c., zgodnie z którym "[s]trony są obowiązane wskazywać dowody dla stwierdzenia faktów, z których wywodzą skutki prawne". Powołane przepisy ustawy równościowej wprowadzają bowiem zasadę tzw. przeniesionego ciężaru dowodu, według której podmiot (powód) jest zobowiązany jedynie do uprawdopodobnienia okoliczności, że została naruszona wobec niego zasada równego traktowania. Pozwany musi natomiast wykazać, że nie dopuścił się jej naruszenia ${ }^{38}$. Na osobie dyskryminowanej spoczywa jedynie ciężar uprawdopodobnienia faktu nierównego traktowania ${ }^{39}$. Jeżeli strona pozwana nie przedstawi dowodów, że kierowała się obiektywnymi kryteriami, jej działanie powinno zostać uznane przez sąd za naruszenie zasady równego traktowania, co w konsekwencji będzie skutkować uwzględnieniem powództwa ${ }^{40}$. Z powyższego wynika, że ustawodawca oparł konstrukcję powództwa przeciw dyskryminacji na domniemaniu faktycznym i odwróceniu ciężaru dowodu.

\footnotetext{
${ }^{37}$ Ustawa z dnia 17 XI 1964 r. - Kodeks postępowania cywilnego (tekst jedn. Dz.U. 2016, poz. 1822), dalej „k.p.c.”.

${ }^{38}$ Podobne rozwiązanie ustawodawca zastosował w art. $18^{3 \mathrm{~b}} \mathrm{k} . \mathrm{p}$.

${ }^{39}$ Należy podkreślić, że uprawdopodobnienie różni się od udowodnienia tym, że możliwe jest stwierdzenie wysokiego prawdopodobieństwa (a nie pewności) zaistnienia przypadku dyskryminacji, jeżeli weźmie się pod uwagę chociażby spójność wersji zdarzeń zaprezentowanych przez powoda.

${ }^{40} \mathrm{~K}$. Kędziora, Uwagi do art. 14, w: Ustawa o wdrożeniu niektórych przepisów Unii Europejskiej..., s. 203-206.
} 
Rozwiązanie przyjęte przez ustawodawcę jest słuszne, gdyż jak pokazują analogiczne przypadki zaistniałe na kanwie przepisów prawa pracy, udowodnienie dyskryminacji jest często trudne. Osoby dotknięte dyskryminacją, molestowaniem, molestowaniem seksualnym zasługują na szczególną ochronę ze strony prawodawcy. Odwrócenie ciężaru dowodu czyni z powództwa realny instrument ochrony ${ }^{41}$. W przeciwnym wypadku analizowane powództwo miałoby charakter pozorny, powielając rozwiązania przyjęte na gruncie Kodeksu cywilnego (art. 23 k.c.).

Na zasadność tego rodzaju rozwiązań przyjętych przez ustawodawcę wskazał w swym orzecznictwie Sąd Najwyższy (SN), który co prawda wypowiadał się o rozwiązaniach prawnych obecnych w Kodeksie pracy, niemniej jednak jego ustalenia mają charakter generalny i uniwersalny. W orzeczeniu z 6 kwietnia 2017 r. SN podniósł, że pracownik może być „z natury rzeczy” obarczony tylko wstępną fazą ciężaru dowodu dyskryminacji, tj. ciężarem dowodu nierównego traktowania, gdyż to pracodawca zna jego rzeczywistą przyczynę i jest $\mathrm{w}$ stanie obronić się przed domniemaniem faktycznym dyskryminacji, jeśli wykaże racjonalne i usprawiedliwione przesłanki zróżnicowania. Obarczenie pracownika pełnym ciężarem dowodu dyskryminacji sprowadziłoby zasadę równego traktowania do całkowitej fikcji, dlatego też prawodawca słusznie postanowił przerzucić na pracodawcę obowiązek dowodzenia przyczyny nierównego traktowania ${ }^{42}$.

Podmiot, który w sposób należyty uprawdopodobni naruszenie zasady równego traktowania, ma, o czym była już mowa, prawo do odszkodowania, którego źródłem normatywnym jest art. 13 ust. 1 u.o.r. Przepis art. 13 ust. 2 u.o.r. stanowi, że "[w] sprawach naruszenia zasady równego traktowania stosuje się Kodeks cywilny". Odesłanie do tej ustawy rodzi konieczność ustalenia wzajemnych relacji pomiędzy prawem do odszkodowania w ustawie równościowej i w Kodeksie cywilnym. W pierwszej kolejności należy podkreślić, że „odszkodowanie” określone w art. 13 u.o.r. odbiega od klasycznej definicji odszkodowania zawartej w przepisie art. 361 k.c., głównie z tego względu, że pojęcie "odszkodowanie" użyte w Kodeksie cywilnym nie konsumuje pojęcia "zadośćuczynienie”. W myśl art. 361 k.c. szkoda może występować w dwojakiej postaci: może obejmować straty, które poszkodowany

${ }^{41}$ Podobnie K. Gonera, Rozkład ciężaru dowodu w sprawach o dyskryminację w zatrudnieniu w orzecznictwie SN, s. 11-15, http://www.ptpa.org.pl/site/assets/files/1029/ciezar_ dowodu_w_sprawach_o_dyskryminacje_21_wrzesnia_2011.pdf (dostęp: 24 VII 2017).

42 Wyrok SN z 6 IV 2017 r., sygn. III PK 100/16, Legalis nr 1657567. 
poniósł (damnum emergens) ${ }^{43}$ albo też utratę korzyści, które mógłby osiągnąć, gdyby szkody mu nie wyrządzono (lucrum cessans) ${ }^{44}$. W przypadku zaś dyskryminacji osoby pokrzywdzone zwykle doznają szkód o charakterze niemajątkowym, naruszana bowiem jest ich godność ${ }^{45}$. Każdy przejaw dyskryminacji stanowi naruszenie godności, która jest dobrem osobistym znajdującym się w relacji do sfery osobowości, uzyskującej konkretyzację w poczuciu własnej wartości człowieka oraz uzasadnionym oczekiwaniu szacunku ze strony innych osób ${ }^{46}$. Konieczna jest więc kompensacja nie tylko szkody materialnej, ale przede wszystkim krzywdy ofiarom nierównego traktowania ${ }^{47}$. Sąd Najwyższy "odszkodowanie” za dyskryminację traktuje bardziej jako zadośćuczynienie za doznaną krzywdę aniżeli rekompensatę za poniesioną szkodę majątkową ${ }^{48}$. Tym samym należy odwołać się do wykładni pojęcia "zadośćuczynienie”, którego istotą jest rekompensowanie uszczerbku w dobrach osobistych (szkody niemajątkowej) w takim zakresie, w jakim taka rekompensata, ze względu na szczególny charakter tych dóbr, jest możliwa za pomocą świadczeń pieniężnych. Zadośćuczynienie ma na celu kompensatę nie tylko cierpień fizycznych, ale również niekorzystnych następstw zdarzenia w sferze psychiki poszkodowanego, i ma przywrócić poszkodowanemu równowagę emocjonalną naruszoną przez doznane cierpienia psychiczne. Dlatego też należy konstatować, że wysokość rekompensaty powinna być uzależniona od okoliczności danej sprawy

${ }^{43}$ Przez pojęcie damnum emergens przyjęto rozumieć każde pogorszenie się sytuacji majątkowej poszkodowanego wskutek zmniejszenia się posiadanych aktywów lub też zwiększenia jego pasywów. Zmniejszenie aktywów następuje przez utratę, ubytek lub zniszczenie poszczególnych elementów majątkowych, które dotąd przysługiwały poszkodowanemu.

${ }^{44}$ K. Zagrobelny, Uwagi do art. 361 k.c., w: Kodeks cywilny. Komentarz, pod red. E. Gniewka, P. Machnikowskiego, Warszawa 2017.

${ }^{45}$ Podobne stanowisko zajął SN w wyroku z 11 IV 2006 r. (sygn. I PK 169/05, OSNP 2007, nr 7-8, poz. 93), w którym podniósł m.in., że „dyskryminacja jest nieuchronnie związana z naruszeniem godności drugiego człowieka, a poszanowanie tej godności jest nakazem nie tylko prawnym, lecz również moralnym".

${ }^{46} \mathrm{~W}$ orzecznictwie jednoznacznie przyjmuje się, że godność zaliczana jest do katalogu dóbr osobistych, zob. orzeczenie SN z 24 IX 2015 r., sygn. V CSK 741/14, Legalis nr 1358761.

${ }^{47}$ Do takiej konstatacji można dojść chociażby na podstawie wyroku Sądu Apelacyjnego (SA) w Białymstoku z 15 I 2016 r. (sygn. I Aca 801/15, LEX nr 1971101), w którym podniesiono, że pojęcie czci zawiera w sobie dwa aspekty: zewnętrzny (dobre imię, dobra opinia, dobra sława) oraz wewnętrzny (godność osobista, wyobrażenie o własnej wartości).

${ }^{48}$ Wyrok SN z 3 IV 2008 r., sygn. II PK 286/07, OSNP 2009, nr 15-16, poz. 202. 
i musi mieć charakter proporcjonalny, skuteczny oraz zniechęcający (prewencyjny $)^{49}$. Z perspektywy ustawy równościowej istotny jest charakter prewencyjny, który stanowi novum w stosunku do zadośćuczynienia w rozumieniu prawa cywilnego. Ten aspekt powinien brać pod uwagę sąd rozpoznający powództwo ${ }^{50}$. Przyznawanie pokrzywdzonym podmiotom rekompensaty proporcjonalnej do doznanej krzywdy może przyczynić się do zmniejszenia przejawów zjawisk dyskryminacyjnych w dalszej perspektywie ${ }^{51}$.

Ustawodawca określił $\mathrm{w}$ art. 15 u.o.r., że termin przedawnienia roszczeń z tytułu naruszenia zasady równego traktowania wynosi trzy lata od dnia powzięcia przez poszkodowanego wiadomości o naruszeniu zasady równego traktowania, nie więcej jednak niż pięć lat od zaistnienia zdarzenia stanowiącego naruszenie tej zasady. Konstrukcja tego przepisu jest analogiczna do instytucji przedawnienia szkody wyrządzonej czynem niedozwolonym, regulowanej w art. $442^{1}$ k.c. Zauważyć również należy, że dochodzenie roszczeń na podstawie przedmiotowej ustawy w żaden sposób nie pozbawia pokrzywdzonego prawa do dochodzenia kolejnych roszczeń na podstawie przepisów innych ustaw (art. 16 u.o.r.).

\section{Stosowanie ustawy równościowej w praktyce orzeczniczej}

W pierwszej kolejności należy odnotować, że do sądów powszechnych wnoszonych jest bardzo niewiele spraw, w których roszczenia wywodzone są z art. 13 u.o.r. Zgodnie ze statystykami prowadzonymi przez Ministerstwo Sprawiedliwości w 2016 r. do sądów wpłynęło dwadzieścia spraw cywilnych o odszkodowania. Żadna z wniesionych spraw nie zakończyła się uwzględnieniem żądania powoda ${ }^{52}$. Z kolei monitoring skuteczności przeprowadzony przez Fundację „Równość. INFO” w ramach projektu "Mocna straż - wzmocnienie działań kontrolnych organizacji, grup nieformalnych i obywateli/ek" ukazał, że często dane

\footnotetext{
${ }^{49}$ Wyrok SN z 7 I 2009 r., sygn. III PK 43/08, LEX nr 577695.

${ }^{50}$ Podobne stanowisko zajęła również RPO w wystąpieniu z dnia 28 V 2012 r., sygn. RPO-687085-I/12/KW/MW.

${ }^{51}$ Wyrok TS z 17 XII 2015 r. w sprawie Maria Auxiliadora Arjona Camacho vs Securitas Seguridad Espana SA, nr skargi C-407/14.

${ }^{52}$ Wydział Statystyki Informacji Zarządczej, Departament Strategii i Funduszy Europejskich Ministerstwa Sprawiedliwości, Ewidencja spraw cywilnych z tytułu naruszenia zasady równego traktowania, http://isws.ms.gov.pl/pl/baza-statystyczna/opracowaniajednoroczne/rok-2016/ (dostęp: 31 VII 2017).
} 
przekazywane przez Ministerstwo Sprawiedliwości na temat spraw toczących się na podstawie ustawy równościowej nie są zgodne ze stanem faktycznym. Autorzy raportu wskazują między innymi na przypadki w sądach rejonowych w Sosnowcu i Pszczynie, w których to sądy początkowo informowały, że na wokandzie były rozpatrywane sprawy na podstawie ustawy równościowej, jednakże analiza akt prowadziła do wniosku, że sprawy były oparte na naruszeniu zasady równego traktowania $\mathrm{w}$ zatrudnieniu i toczyły się $\mathrm{z}$ wykorzystaniem przepisów Kodeksu pracy. W związku z powyższym uznać należy, że w sądach tych nie odnotowano żadnej sprawy opartej na art. 13 u.o.r. ${ }^{53}$ Autor opracowania zwrócił się do dwudziestu sądów okręgowych z prośbą o udzielenie informacji dotyczącej zastosowania przedmiotowej ustawy w okresie od 2011 do 2016 r. Osiemnaście sądów nie odnotowało takich spraw $^{54}$. Jedynie Sąd Okręgowy w Warszawie przeprowadził dwie tego rodzaju sprawy, z czego tylko jedna zakończyła się uwzględnieniem powództwa. Należy jednak zauważyć, że sądy nie mają obowiązku prowadzenia odrębnej ewidencji spraw prowadzonych na podstawie ustawy równościowej. Dlatego też należy w pełni podzielić postulat Sądu Najwyższego oraz Rzecznika Praw Obywatelskich stworzenia efektywnego systemu pozwalającego na ich oddzielne ewidencjonowanie. Pozwoli to na ocenę skuteczności wprowadzonego przez ustawodawcę instrumentu mającego na celu walkę z dyskryminacją.

Niski odsetek spraw inicjowanych $\mathrm{w}$ drodze powództwa przeciw dyskryminacji budzi wiele wątpliwości i pytań. Z jednej strony może to wynikać z niedoskonałości omawianej ustawy, co w konsekwencji powoduje, że nie jest ona efektywnym narzędziem $w$ dochodzeniu praw jednostki przed sądem. $Z$ drugiej strony może to być rezultat nieznajomości przepisów tego aktu oraz niskiej świadomości społecznej i możliwości dochodzenia swych praw w drodze powództwa przeciw dyskryminacji. Dlatego też za zasadny należy uznać postulat o zwiększeniu działalności informacyjnej dotyczącej głównych założeń ustawy.

${ }^{53}$ Wyniki monitoringu pokazuja, że dane, które Ministerstwo Sprawiedliwości przekazało Rzecznikowi Praw Obywatelskich (trzydzieści spraw w 2011 r.) czy też w odpowiedzi na zapytania ówczesnego posła Roberta Biedronia (sześć spraw w 2012 r.), nie mają pokrycia w rzeczywistości i nie odzwierciedlają stanu faktycznego. W odpowiedzi na zapytania wysłane do sądów powszechnych uzyskano ostateczną informację, że przeprowadzono pięć postępowań z zastosowaniem przepisów ustawy równościowej.

${ }^{54}$ Sąd Okręgowy (SO) w Lublinie odmówił udzielenia informacji publicznej, wskazując, że zapytanie autora nie przedstawia interesu publicznego, dlatego też Prezes Sądu wydał decyzję negatywną. 
Właściwym rozwiązaniem wydaje się być przeprowadzenie medialnej kampanii informacyjnej, która zwiększy świadomość społeczną, że w razie naruszenia zasady równego traktowania osoby dotknięte tym zjawiskiem mogą samodzielnie wystąpić na drogę sądową bądź też uzyskać profesjonalną pomoc u Rzecznika Praw Obywatelskich lub u Pełnomocnika Rządu do Spraw Równego Traktowania ${ }^{55}$. Ponadto w kompetencji RPO nie leży wyłącznie udzielenie stosownej informacji, ale także prawo do wszczęcia lub przyłączenia się do postępowania toczącego się przed sądem powszechnym ${ }^{56}$. Według danych Biura RPO Rzecznik przyłączył się do zaledwie dwóch postępowań sądowych wszczętych na podstawie ustawy równościowej ${ }^{57}$. Skierowane skargi dotyczyły dyskryminacji ze względu na macierzyństwo w procesie rekrutacji, a także naruszenia zasady równego traktowania ze względu na płeć w dostępie do dóbr i usług.

Spośród spraw, które wpłynęły do sądów powszechnych i zakończyły się uwzględnieniem powództwa oraz zasądzeniem dochodzonego odszkodowania na rzecz powoda, jako pierwszą należy wskazać sprawę zakończoną wyrokiem z dnia 9 lipca 2014 r. zawisłą przed Sądem Rejonowym dla Warszawy-Śródmieście ${ }^{58}$. W przedmiotowym postępowaniu sąd orzekł, że doszło do dyskryminacji bezpośredniej w obszarze zatrudnienia niepracowniczego, ze względu na orientację seksualną. Orzeczenie to zapadło na kanwie następującego stanu faktycznego. Podczas krakowskiego marszu równości w 2012 r. powód szedł w pierwszym szeregu, o czym z przekazów medialnych dowiedzieli się jego współpracownicy i przełożeni. Jeszcze tego samego dnia powód otrzymał od bezpośredniego przełożonego wiadomość tekstową informującą o zwolnieniu go z pracy. Ponadto przełożeni kierowali pod adresem powoda obraźliwe komentarze odnoszące się do jego domniemanej orientacji

${ }^{55}$ Zgodnie z art. 18 u.o.r. wykonywanie zadań dotyczących realizacji zasady równego traktowania powierza się Rzecznikowi Praw Obywatelskich oraz Pełnomocnikowi Rządu do Spraw Równego Traktowania.

${ }^{56}$ Zgodnie z art. 14 pkt 4 Ustawy z dnia 15 VII 1987 r. o Rzeczniku Praw Obywatelskich (tekst jedn. Dz.U. 2017, poz. 958) Rzecznik może żądać wszczęcia postępowania w sprawach cywilnych, jak również wziąć udział w każdym toczącym się już postępowaniu, na podstawie zaś art. 14 pkt 6 tego aktu może wnosić skargi do sądu administracyjnego, a także uczestniczyć w tych postępowaniach na prawach przysługujących prokuratorowi.

${ }^{57}$ Dane uzyskane przez autora z Zespołu do Spraw Równego Traktowania Biura RPO.

${ }^{58}$ Wyrok Sądu Rejonowego dla Warszawy-Śródmieścia z 9 VII 2014 r., sygn. VI C 402/13, niepubl. 
seksualnej, co było związane z jego udziałem w marszu. Ostatecznie $z$ powodem rozwiązano umowę zlecenia. $W$ uzasadnieniu wyroku sąd podniósł, że "dyskryminacja może przybrać tę szczególną formę, w której bez znaczenia pozostaje, czy dana osoba posiada cechę, ze względu na którą jest odróżniana w pewnej grupie. Dyskryminacja polega bowiem również na przypisaniu danej osobie cechy i dla samego wystąpienia zjawiska dyskryminacji posiadanie tej cechy ma znaczenie irrelewantne. Zjawisko to nosi miano dyskryminacji przez asocjację, czyli przyłączenia danej osoby - z uwagi na subiektywne zapatrywania - do grupy osób dyskryminowanych". Dlatego też należy podkreślić, że regulacje ustawy równościowej, wskazując na cechy chronione, nie korelują jednoznacznie dyskryminacji z faktem posiadania przez daną osobę cechy objętej ochroną. W związku z tym roszczenia za doznaną dyskryminację mogą zgłaszać również osoby, które w rzeczywistości nie są nosicielami określonej cechy. Wystarczająca będzie okoliczność, że osoba doznała nierównego traktowania ze względu na cechę należącą do środowiska bądź do osoby bliskiej, z którą się utożsamia ${ }^{59}$. Identyczne będzie zjawisko, w którym to dana cecha będzie błędnie przypisana przez podmiot dopuszczający się dyskryminacji ${ }^{60}$. Należy również odnieść się do kwestii związanej z zasądzonym odszkodowaniem na rzecz powoda. Sąd, orzekając odszkodowanie, zgodnie $z$ dyspozycją art. 13 ust. 2 u.o.r. odwołał się do art. $361 \S 1$ i art. $363 \S 1$ k.c. Rozpatrujący apelację strony powodowej od wyżej wymienionego orzeczenia sądu I instancji Sąd Okręgowy w Warszawie zaznaczył, że rację miał powód, wskazując, że odszkodowanie z art. 13 u.o.r. nie podlega rozróżnieniu na naprawienie szkody majątkowej i niemajątkowej (krzywdy). Zdaniem sądu wynika to z art. 13 ust. 2 u.o.r., który zawiera odesłanie do Kodeksu cywilnego. Przepis ten wyraźnie rozróżnia w osobnych jednostkach redakcyjnych Kodeksu odpowiedzialność za szkodę majątkową i niemajątkową. Dlatego też, gdyby ustawodawca $\mathrm{w}$ istocie zechciał rozróżnić $\mathrm{w}$ ustawie równościowej kwestie odpowiedzialności za szkodę majątkową i za krzywdę, zostałoby to rozróżnione już w samej treści przepisu ${ }^{61}$.

Inna sprawa oparta na ustawie równościowej toczyła się przed Sądem Okręgowym w Warszawie i została wszczęta na kanwie następującego stanu faktycznego. Powódka niebędąca obywatelką Rzeczypospolitej

\footnotetext{
${ }^{59} \mathrm{Na}$ przykład heteroseksualni działacze i działaczki organizacji LGBT.

${ }^{60} \mathrm{Na}$ przykład domniemanie, że modnie ubrany mężczyzna jest homoseksualistą.

${ }^{61}$ Wyrok SO w Warszawie z 18 XI 2015 r., sygn. V Ca 3611/14, niepubl.
} 
za granicą ukończyła studia aktorskie i miała doświadczenie zawodowe. W chwili zaistnienie zdarzenia mieszkała już Polsce. Chcąc zwiększyć swoje szanse na znalezienie pracy w zawodzie, zdecydowała się w 2013 r. aplikować na wydział reżyserski akademii teatralnej. Jak twierdziła powódka, od początku utrudniano jej proces rekrutacji, m.in. wprowadzając ją w błąd co do wymogów formalnych związanych z aplikacją na wydział. W konsekwencji powódka zwróciła się do Ministerstwa Kultury z wnioskiem o interwencję w przedmiotowej sprawie. W wyniku przeprowadzonej interwencji umożliwiono powódce złożenie dokumentów. Jednak egzemplarz reżyserski powódki został oceniony na zero punktów w skali dziesięciopunktowej. Powódka, chcąc uzyskać informację na temat przyczyn zdobycia tak małej liczby punktów, zwróciła się do władz uczelni o stosowne uzasadnienie. Dziekan uczelni w trakcie rozmowy z powódką jednoznacznie stwierdził, że uczelnia preferuje obywateli polskich, a powódka egzemplarz reżyserski sporządziła w języku obcym ${ }^{62}$. Powództwo zostało jednak w całości oddalone zarówno przez sąd I, jak i II instancji63. Sąd Okręgowy zaznaczył, że „pozwanej Akademii [...] nie można zarzucić dyskryminacji G.W. ze względu na jej ukraińską narodowość. To nie pochodzenie było przyczyną jej nieprzyjęcia na studia, ale niska merytorycznie wartość przedstawionej pracy". Sąd Okręgowy nie dysponował żadnymi dowodami, które pozwoliłyby na zakwestionowanie oceny "0", jaką egzemplarzowi reżyserskiemu wystawili niezależnie od siebie dwaj recenzenci. Argumentacja została następnie w całości podzielona przez Sąd Apelacyjny.

Przed Sądem Okręgowym w Warszawie toczyło się także postępowanie, dla którego przyczynkiem do zainicjowania był następujący stan faktyczny: powódka brała udział w rozmowie kwalifikacyjnej, na którą została zaproszona pomimo braku wcześniejszej aplikacji do konkursu. Rozmowa została przeprowadzona w związku z rekrutacją na stanowisko osoby wykonującej prace biurowe na podstawie umowy zlecenia. Podczas rozmowy kwalifikacyjnej padły pytania o doświadczenie zawodowe. Została sprawdzona umiejętność pisania bezwzrokowego. Następnie powódka została zapytana przez osobę prowadzącą rekrutację, czy ma małoletnie dzieci i czy będzie w stanie zapewnić im opiekę na czas pracy. Powódka odmówiła odpowiedzi na to pytanie, używając

${ }^{62}$ Monitoring skuteczności funkcjonowania Ustawy z dnia 3 grudnia 2010 r., https://row nosc.info/media/uploads/raport_do_druku.pdf (dostęp: 31 VII 2017).

${ }^{63}$ Wyrok SA w Warszawie - I Wydział Cywilny z 23 VIII 2016 r., sygn. I ACa 1522/15, Legalis nr 1546506. 
słów: „myślę, że nie powinnam odpowiadać na to pytanie”. Brak odpowiedzi na pytanie skutkował natychmiastowym zakończeniem rozmowy. Powódka w tym przypadku nie została zatrudniona u pozwanego ${ }^{64}$. Do postępowania włączył się Rzecznik Praw Obywatelskich, jednakże powództwo zostało oddalone. W uzasadnieniu sąd podniósł, że nie budzi wątpliwości, iż pytanie związane z rodzicielstwem powódki nie powinno w ogóle paść ze strony pozwanego. Przekraczało ono bowiem granice prywatności powódki usankcjonowane w świadomości społecznej za sprawą regulacji art. $22^{1}$ k.p. Jednak trudno przyjąć, by pytanie dotyczące rodzicielstwa powódki wiązać się mogło z jakimkolwiek upokorzeniem czy naruszeniem godności. Fakt, że powódka jest matką, pozwala na domniemanie, iż nie stanowi to dla niej źródła upokorzenia. Sąd ponadto nie uwzględnił argumentu powódki, że ta poczuła się nieprzydatna zawodowo, co wpłynęło na jej samoocenę, powodując brak wiary w znalezienie pracy ${ }^{65}$.

Sąd oddalił również powództwo w sprawie kobiety, która w dniu 2 listopada 2014 r. wraz z mężem, wówczas sześciomiesięczną córką oraz siostrą udała się do restauracji, której właścicielem był podmiot pozwany ${ }^{66}$. $\mathrm{W}$ czasie wizyty w restauracji, kiedy wyżej wymienione osoby spożywały już posiłek, kobieta postanowiła nakarmić piersią swoje dziecko. Jednakże na tę okoliczność natychmiast zareagował jeden z pracowników restauracji, który zwrócił uwagę powódce, że w tym miejscu nie może tego zrobić. Pracownik wskazał, że takie zachowanie jest sprzeczne $\mathrm{z}$ regulaminem obowiązującym w restauracji. Zaproponował jednocześnie alternatywne rozwiązanie. Wskazał, że tę czynność powódka może wykonać w toalecie lub w specjalnie wyznaczonym do tego celu miejscu. Kobieta się jednak na tę propozycję nie zgodziła ${ }^{67}$. Powódka uznała, że jest to dla niej upokarzające, gdyż toaleta nie była jej zdaniem odpowiednim miejscem do spożywania posiłku przez dziecko, a dla niej oznaczałoby to konieczność

${ }^{64}$ Ibidem. Ponadto dane uzyskane przez autora z Zespołu do Spraw Równego Traktowania Biura RPO.

${ }^{65}$ Uzasadnienie do wyroku SO w Warszawie z 6 VIII 2015 r., sygn. XXV C 96/15, niepubl.

${ }^{66}$ Ze względu na anonimizację danych personalia osób oraz miejscowość nie są znane.

${ }^{67}$ Strony postępowania złożyły w tym zakresie sprzeczne zeznania, gdyż powódka podnosiła, że kelner wskazał wpierw łazienkę, a następnie miejsce znajdujące się przy łazience, które było znacznie lepiej przystosowane do tego rodzaju czynności, podczas gdy strona pozwana podnosiła, że powódka od razu została poproszona o przejście do wydzielonej strefy znajdującej się przed łazienką. Sąd, opierając się na swoim doświadczeniu życiowym oraz zasadach logiki, uznał za wiarygodne środki dowodowe strony pozwanej. 
odejścia od stolika, przy którym jadła i przy którym siedzieli jej najbliżsi, z którymi chciała spędzić tego dnia czas. Strony konfliktu nie doszły do porozumienia i wskazane osoby, z powodu konieczności nakarmienia dziecka, zostały zmuszone do opuszczenia restauracji. Mimo że w ich ocenie otrzymały usługę gorszej jakości, uregulowały cały rachunek za usługę. Sąd Okręgowy w Gdańsku oddalił przedmiotowe powództwo ${ }^{68}$. W uzasadnieniu sąd podniósł, że materiał dowodowy zgromadzony w sprawie świadczy o tym, że nie doszło do nierównego traktowania pod postacią nakazania określonego zachowania. Miało miejsce jedynie przekazanie prośby innych klientów o dyskretniejsze wykonywanie czynności związanych z koniecznością zaspokojenia potrzeb żywieniowych dziecka, ewentualnie wykonanie ich w innym, mniej publicznym miejscu. Zdaniem sądu przekazanie prośby innych osób nie oznacza nierównego traktowania i praktyka stosowana przez właściciela restauracji w żaden sposób nie narusza zasad równego traktowania.

$Z$ perspektywy omawianej materii relewantna jest również sprawa Adama J., drukarza, który z powodu przekonań odmówił wydrukowania plakatów przedstawicielowi fundacji LGBT. Obwiniony w marcu 2017 r. został uznany za winnego popełnienia wykroczenia z art. 138 Kodeksu wykroczeń ${ }^{69}$. Przepis ten inkryminuje odmowę świadczenia, przez osobę zajmującą się świadczeniem usług, na rzecz drugiej osoby bez uzasadnionej przyczyny. Od przedmiotowego orzeczenia złożono apelację, jednakże wyrok sądu I instancji został utrzymany. W ustnym uzasadnieniu do orzeczenia sąd podkreślił, że "[w]yrok sądu odwoławczego nie ma zabarwienia ideologicznego. Sąd nie wypowiada się ani za, ani przeciw orientacji grup LGBT albo pana obwinionego. Jest wyrazem tego, że zasada równości wobec prawa jest nadrzędna". Sąd wskazał, że "ta sprawa ma nas wszystkich czegoś nauczyć i załagodzić konflikt. Skłonić do refleksji i do tego, byśmy nie starali się patrzeć na innych przez pryzmat wyznawanych przez siebie wartości, bo nie mamy żadnej gwarancji, że nasze są dobre, a czyjeś są złe ${ }^{\prime \prime 70}$. Niewątpliwie, zaistniały stan faktyczny mógłby stanowić podstawę do wszczęcia postępowania na podstawie ustawy równościowej, a nie tylko Kodeksu wykroczeń.

${ }^{68}$ Wyrok SO w Gdańsku z 1 XII 2016 r., sygn. I C 206/15, niepubl.

${ }^{69}$ Ustawa z dnia 20 V 1971 r. Kodeks wykroczeń (Dz.U. 2015, poz. 1094).

${ }^{70}$ A. Grzelak-Michałowska, Tak działaja polskie sady. Utrzymano wyrok dla drukarza, który nie chciał robić plakatów dla fundacji LGBT, wPolityce.pl, https://wpolityce.pl/ polityka/341626-tak-dzialaja-polskie-sady-utrzymano-wyrok-dla-drukarza-ktory-niechcial-robic-plakatow-dla-fundacji-lgbt (dostęp: 20 XI 2017). 
Należy jednak do orzeczenia sądów obu instancji oraz potencjalnego postępowania na drodze cywilnej podejść z pewną ostrożnością. Sąd zasadnie podniósł, że zasada równości wobec praw jest niezwykle doniosła w systemie prawnym i w społeczeństwie, jednakże z pola widzenia nie należy również tracić innej zasady - wolności umów. Wolność umów, najogólniej ujmując, polega przede wszystkim na respektowaniu woli stron w kształtowaniu treści nawiązywanych stosunków prawnych ${ }^{71}$. Jest to szczególny „wycinek” wolności człowieka (art. 31 Konstytucji $\mathrm{RP})$, który nie został unormowany wprost w przepisach konstytucyjnych. Oparcia normatywnego dla swobody umów można poszukiwać z jednej strony w konstytucyjnej zasadzie wolności każdego człowieka (art. 31 ust. 1 Konstytucji RP), z drugiej w zasadzie wolności gospodarczej (art. 22 Konstytucji RP) ${ }^{72}$. W orzecznictwie TK podnosi się, że swoboda umów wynika z art. 20 i 22 Konstytucji RP i statuowanej w tych przepisach wolności działalności gospodarczej ${ }^{73}$. Usługi związane z drukowaniem plakatów nie są reglamentowane. Mają charakter powszechnie dostępny, tym samym prawa usługobiorcy w żaden sposób nie zostały ograniczone, gdyż ten mógł skorzystać z usług innego przedsiębiorcy. Sądy obu instancji nie zwróciły uwagi na te aspekty, dlatego też w przypadku skierowania przez Rzecznika Praw Obywatelskich bądź Prokuratora Generalnego skargi kasacyjnej Sąd Najwyższy będzie musiał rozstrzygnać konflikt między dwiema, w tym przypadku sprzecznymi, zasadami, co prawda na kanwie Kodeksu wykroczeń, ale nie ulega wątpliwości, że materia ta jest relewantna z perspektywy powództwa przeciw dyskryminacji. Na podobne wątpliwości wskazuje obrońca obwinionego adw. Bartosz Lewandowski, który podnosi, że "przepis art. 138 Kodeksu wykroczeń dotyczy wszystkich osób zajmujących się świadczeniem usług, a więc szerokiego kręgu. Nie można godzić się z tym, by każdy, kto publicznie ogłosi, że świadczy takie a takie usługi, był zmuszony do ich świadczenia każdemu klientowi. Pod ochroną tego przepisu pozostają nie tylko konsumenci, a zatem osoby fizyczne, ale również osoby prawne, co potęguje zagrożenie dla wolności działalności gospodarczej i swobody działalności gospodarczej"74.

${ }^{71}$ Wyrok TK z 13 IX 2005 r., sygn. K 38/04, OTK-A 2005, nr 8, poz. 92.

${ }^{72}$ Ibidem.

${ }^{73}$ Wyrok TK z 22 V 2013 r., sygn. P 46/11, OTK-A 2013, nr 4, poz. 42.

${ }^{74}$ A. Łukasiewicz, Firmy nie mogą dowolnie dobierać sobie klientów, "Rzeczpospolita”, http://www.rp.pl/Konsumenci/311099880-Firmy-nie-moga-dowolnie-dobierac-sobieklientow.html (dostęp: 20 XI 2017). 
Powyżej przedstawione przykłady spraw zawisłych przed sądami powszechnymi wskazują, że dotychczas sądy bardzo rygorystycznie badaja, czy doszło do naruszenia przepisów ustawy równościowej. Linia orzecznicza nie jest korzystna dla osób wnoszących powództwa. Powodem takiego stanu może być okoliczność, że ustawa równościowa jest swego rodzaju novum również dla samych sędziów. Na pewno upowszechnienie wiedzy o powództwie przeciw dyskryminacji spowoduje zwiększenie liczby spraw. Warto zastanowić się nie tylko nad postulatem podnoszenia wiedzy obywateli o tytułowej instytucji, ale także i przede wszystkim wiedzy osób wykonujących zawody prawnicze.

\section{Podsumowanie}

Ustawa równościowa jest ważnym krokiem ku ochronie społeczeństwa przed dyskryminacją. Implementacja dyrektyw unijnych otworzyła drogę do inicjowania postępowań sądowych w drodze powództwa przeciw dyskryminacji. Ukształtowany model powództwa przerzuca ciężar dowodu na pozwanego, $\mathrm{tj}$. podmiot stosujący praktyki niedozwolone w świetle ustawy. Odpowiednie stosowanie przepisów ustawy pozwala nie tylko na zrekompensowanie ofierze dyskryminacji doznanej krzywdy, ale jest też środkiem zapewniającym prewencję ogólną przed tego rodzaju zachowaniami. Z drugiej jednak strony społeczeństwo nie ma dostatecznej wiedzy o tytułowej instytucji. Brak odpowiedniej kampanii informacyjnej, szkoleń dla aplikantów i prawników powoduje, że środek ten nie jest efektywny. Do tego przyczynia się również praktyka orzecznicza sądów, które niechętnie uwzględniają powództwa przeciw dyskryminacji.

\section{ACTION AGAINST DISCRIMINATION IN THE ACT OF 3 DECEMBER 2010 ON THE IMPLEMENTATION OF CERTAIN EUROPEAN UNION REGULATIONS ON EQUAL TREATMENT}

\section{Su m mary}

Discrimination is a phenomenon that has been existing in our society for many years. The main cause of increased legislative activity in European countries is the action of the European Union, which has issued a number of directives dealing with the problem of discrimination. Poland, as a member of the European Union, was obliged to implement anti-discrimination directives. The legislator did this by 
enacting the Act of 3 December 2010 on the implementation of certain European Union regulations on equal treatment (hereafter: the equality statute). The equality statue was a good step towards combating discrimination in areas such as the provision of services or capital flow. The legislator has also pointed to discriminatory features, including race, age, disability, sex, or sexual orientation. These features cannot serve as a basis for differentiating the legal position of legal entities. In carrying out a comprehensive analysis of the subject matter, the study presented in this article covered: the normative grounds of an anti-discrimination lawsuit, the right to compensation, which deviates significantly from the definition set out in Article 361 of the Civil Code, the substantive and legal grounds for action, the principles and the procedure for claiming compensation. The article also deals with the effectiveness of the application of the measure in the jurisprudence. To that end, the study examined the case law of common courts dealing with the facts related to the equality law. The Ombudsman and other anti-discrimination authorities have also been contacted for information on the use of this measure. The paper identifies as well, the potential solutions aimed at increasing the effectiveness and frequency of the use of anti-discrimination lawsuits before Polish common courts.

Keywords: action against discrimination - discrimination - right to equality 